\title{
O Secretário-Geral da ONU: Líder ou Servidor Internacional?
}

(O DIFICIL PROCESSO DE SUA ESCOLHA)

A. FONSECA PIMENTEL

(Autor da obra recentemente publicada "A PAZ E O PÃO - Desafio às Nações Unidas.")

Desde que a ONU foi estabelecida em 1945, muito se tem discutido se o seu Secretário-Geral, previsto no art. 97 da Carta, há de ser um líder ou um servidor internacional.

E como boa parte dos Estados-membros da Organização, notadamente as grandes potências, não se mostram particularmente interessadas em ver surgir no cenário mundial um líder de tal natureza, as respostas têm sido, de preferência, no sentido de que o Secretário-Geral da ONU não deve passar de um servidor internacional, ou seja, o servidor internacional no 1 , com atribuições predominantemente executivas e administrativas e não políticas. Em outras palavras, o dirigente supremo da Organização deve ser um generalista da administração e não um especialista da política.

Por essa razão, nenhum dos três Secretários-Gerais que até hoje exerceram o cargo - Trygve Lie (1946-53), Dag Hammarskjoeld (1953-61) e U Thant (desde 1961) - deixou de ser, às vêzes, duramente criticado pelos governos de alguns países - de um ou de outro dos dois blocos em que se divide bàsicamente o mundo em nossos dias, conforme o caso - por haver adotado, sem autorização da Assembléia-Geral ou do Conselho de Segurança, decisões consideradas de caráter eminentemente político e de relevância para os destinos de boa parcela da humanidade. ${ }^{1}$

1. Para distinção entre política e administração bem como entre decisões políticas e decisões administrativas, veja-se o nosso estudo "Política e Administração" in Revista do Serviço Público, vol. 105, $\mathrm{n} \div 1$, jan./abril 1970, págs. $36 / 42$. 
Líder ou servidor internacional, não importa, o fato é que - Secretário-Geral da ONU, como principal dirigente (chief executive) da Organização, enfeixa em suas mãos uma soma de podêres e atribuições que fazem dêle algo como um pequeno monarca ou soberano, ainda que constitucional, de cêrca de 35.000 servidores que prestam colaboração à Organização na maioria dos países da terra. Mutatis mutandis e guardadas as devidas proporções, bem como a diversidade da missão de cada um, a sua figura, inclusive, não deixa, às vêzes, de lembrar a do próprio Papa. Ambos, com efeito, são singulares ou sui generis, diversamente do que ocorre com os Chefes de Estado, que se contam hoje por quase uma centena e meia em todo o mundo. ${ }^{2}$

Não obstante isso, dentro da Organização a figura do Secretário-Geral - como a do Papa dentro do Vaticano - é a de um verdadeiro Chefe de Estado ou, mais pròpriamente, de Executivo.

$\mathrm{Na}$ verdade, de acôrdo com a estrutura básica da ONU, o Poder Legislativo é ali detido pela Assembléia-Geral, que, reunindo-se, contudo, apenas uma vez por ano, por cêrca de três meses, o delega, em parte e conforme o caso, ao Conselho de Segurança e ao Conselho Econômico e Social, que são órgãos de caráter permanente e atuação contínua.

O Poder Judiciário da Organização se concentra, bàsicamente, em dois órgãos, a saber:

a) a Côrte Internacional de Justiça, no que concerne ao direito internacional público;

b) o Tribunal Administrativo das Nações Unidas, no que concerne ao direito internacional privado, ou, mais especificamente, às relações entre as Nações Unidas e os seus servidores. ${ }^{3}$

Quanto ao Poder Executivo, concentra-se, fundamentalmente, nas mãos do Secretário-Geral, que, ademais, detém, em parcela limitada um pouco de delegação do poder legislativo.

É considerável, pois, a importância da figura do SecretárioGeral, seja qual fôr o prisma através do qual é ela encarada.

2. Para um estudo comparativo mais pormenorizado entre o Vaticano $e$ as Nações Unidas, vejam-se os caps. 6 e 9 de nosso livro A PAZ E O PAOO - Desafio às Nações Unidas, Brasilia, 1970.

3. Há também, em Genebra, o Tribunal Administrativo, com a competência de julgar os litígios entre as diversas organizações da "Família das Nações Unidas" sediadas na Europa e os seus servidores. 
O primeiro Secretário-Geral foi Trygve Lie, de seu nome completo Trygve Halvdan Lie, estadista norueguês nascido em Oslo a 16 de julho de 1896 e falecido a 30 de dezembro de 1968. Homem predominantemente político, havendo exercido em seu país os cargos de Ministro da Justiça (1935-39), do Comércio (1939) e do Comércio, Indústria, Marinha e Pesca (1939-41), interpretou o cargo como sendo de natureza mais política do que administrativa e adotou, conseqüentemente, decisões ousadas que irritaram, não raro, várias das grandes potências. Trygve Lie chegou mesmo a afirmar que "o Secretário-Geral devia ser mais general do que secretário". " Como resultado, a sua administração foi, provàvelmente, a mais controvertida das três, o que o levou a renunciar ao cargo a 10 de novembro de 1952, não obstante haver permanecido em seu exercício até 10 de abril de 1953, quando, após laboriosíssimas negociações, se chegou a um acôrdo sôbre o seu sucessor.

Êste foi Dag Hammarskjoeld, de seu nome completo Dag Hjalmar Agne Carl Hammaskjoeld, diplomata e economista sueco, nascido a 29 de julho de 1905 e morto tràgicamente a 18 de setembro de 1961, quando, no desempenho do cargo de Secretário-Geral, sobrevoava a cidade de Ndola, Rodésia, e aí explodiu o avião em que se dirigia a Catanga para intervir pessoalmente na cessação de fogo entre as fôrças da ONU e as tropas congolesas. Mentalidade mais administrativa do que polítca, Hammarskjoeld teve uma administração mais ou menos da mesma duração da de Trygve Lie, porém mais tranqüila e equilibrada, não obstante o seu trágico fim. ${ }^{5}$

Confrontada em 1953 com o grave problema da renúncia de Trygve Lie, viu-se a ONU dramàticamente a braços em 1961 com o problema mais grave ainda da morte inesperada de Hammarskjoeld, cuja sucessão, diversamente da de Trygve Lie, não comportava adiamento. Em caráter de emergência, reuniu-se - Conselho de Segurança e acordou-se na indicação do nome do diplomata birmanês $U$ Thant, de seu nome completo Sithu $U$ Thant, para assumir interinamente a Secretaria-Geral. No ano seguinte, após verdadeiro estágio probatório, rigorosamente observado por tôdas as potências interessadas, foi U Thant confirmado no pôsto e eleito para um mandato de quatro anos,

4. O trocadilho é perfeito em inglês, idioma em que a palavra "general" pode ser general e geral.

5. Hammarskjoeld era, ademais, um espírito profundamente religioso e, mesmo, quase místico, como se pode ver pela leitura do seu Diário aparecido pòstumamente: markings, by Dag Hammarskjoeld, translated by Leif Sjölberg \& W. H. Auden, with a foreword by W. H. Auden, Faber and Faber, London, 1964. 
a expirar a 31 de dezembro de 1966. Reconduzido em dezembro de 1966 a nôvo mandato, desta vez de cinco anos, completará o atual Secretário-Geral da ONU dez anos de exercício do cargo em dezembro de 1971, quando terá a Organização de enfrentar novamente o espinhoso problema da sua sucessão.

Será $U$ Thant reconduzido a um terceiro período? Tudo indica que não, não só pela sua manifestada relutância, em 1966, em aceitar o segundo mandato, como também pela própria necessidade de renovação que se sente a êsse respeito em muitos setores da Organização.

Acordará o Conselho de Segurança - de cuja recomendação depende a escolha do Secretário-Geral - em um ou alguns nomes a serem submetidos à Assembléia-Geral?

O problema afigura-se quase insolúvel, dadas as divergências que separam atualmente os membros permanentes daquele Conselho, tendo, de um Iado, os E.U.A., a Inglaterra e a China (Nacionalista), de outro, a União Soviética e, numa posição bastante independente, a França. (Isso para não falar na possibilidade de vir a China Continental a ocupar, até lá, o lugar da China Nacionalista no Conselho, o que complicaria ainda mais o problema).

Há, contudo, algumas inferências lógicas ou, pelo menos, plausíveis, que podem ser tiradas do exame da situação.

Em futuro previsível, o Secretário-Geral jamais será um norte-americano ou um russo e, muito dificilmente, um representante de qualquer dos países integrantes da NATO ou do Pacto de Varsóvia.

Assim, a escolha do dirigente supremo da ONU terá de ser procurada, quase necessàriamente, como ocorreu, aliás, com a de U Thant, nos países não comprometidos ou menos comprometidos com a "guerra fria" geral ou com as várias "guerras quentes ou semiquentes" locais atualmente em desenvolvimento no globo. Do contrário, o seu nome não passará o teste inicial no seio do Conselho de Segurança.

Por outro lado, porém, o Secretário-Geral, indicado pelo Conselho de Segurança, é eleito pela Assembléia-Geral, onde as nações subdesenvolvidas representam hoje pràticamente $4 / 5$ dos votos.

Tudo isso levado em conta - as razões do Conselho de Segurança e as razões da Assembléia-Geral -, as chances de fazer o futuro Secretário-Geral estão, em verdade, com alguns dos países da América Latina, África e Ásia, menos comprometidos em qualquer dos conflitos que hoje dividem o mundo. 
Mas, cabe aqui uma pergunta: haverá, realmente, futuro Secretário-Geral se $U$ Thant não se interessar por um terceiro mandato ou não fôr para êle considerado aconselhável?

As substituições do Secretário-Geral, como se deixou entrever, têm constituído, em maior ou menor escala, verdadeira crise para a Organização. Não será difícil, assim, que, em face de dificuldades insuperáveis na escolha do sucessor de U Thant, a União Soviética volte à sua proposta, feita por Khruschiov em 1962 ou 1963, de uma troika para dirigir a Organização, ou seja, um triunvirato composto de um representante do bloco ocidental, um do bloco socialista e um do mundo não alinhado.

Mas, as principais nações do bloco ocidental repeliram enèrgicamente o esquema, sob a alegação de que a direção colegiada viria paralisar ou entorpecer mais ainda a operatividade da Organização, que já é presentemente acusada, não raro, de inércia ou imobilismo.

Assim, ao que tudo indica, a ONU, com crise ou sem crise, terá, em dezembro de 1971, o seu 4?-Secretário-Geral. E o servidor internacional $n \div 1$, ao que também tudo indica, será, como U Thant, cidadão de um país subdesenvolvido dos menos comprometidos em qualquer dos conflitos que hoje dividem o mundo: isso exclui do campo de recrutamento pràticamente tôda a Europa, a América do Norte e boa parte da Ásia e da África, podendo significar, em última análise, a grande oportunidade da América Latina nesse sentido.

Uma coisa, todavia, parece certa, em face da atual evolução dos acontecimentos mundiais.

O próximo Secretário-Geral ou verá o reforçamento das Nações Unidas (para o que lhe caberá contribuir de maneira decisiva, dentro de suas atribuições ou podêres) ou verá o seu sepultamento, à semelhança da Liga das Nações (caso em que êle ficará na História como o coveiro de um dos mais belos sonhos da humanidade ou, em outras palavras, daquilo que John F. Kennedy denominou "the last best hope of mankind"). ${ }^{6}$

6. A. Fonseca Pimentel, A PAZ E O PÃO, pág. 67 e, em especial, todo - Prólogo da obra. 
